\title{
Akrep Antivenomunun İmmunassay Yöntem Üzerindeki İnterferans Etkisinin Deneysel Araştırılması
}

\author{
Ataman GÖNEL \\ Harran Üniversitesi, Tıp Fakültesi, Tıbbi Biyokimya Anabilim Dalı, Şanlıurfa, Türkiye.
}

Geliş Tarihi: 12.05.2018

Kabul Tarihi: 19.11.2018

\begin{abstract}
Özet: Skorpionizmde özgün tedavi yöntemi antivenom kullanımıdır. Antivenomların klinik olarak alerjik reaksiyonlara yol açtı̆̆ı bilinse de antikor özelliğinden dolayı immunassay ölçüm yöntemlerinde oluşturabileceği interferans etkisi bilinmemektedir. İmmunassay metotlar hormon, kardiyak markır, tümör markırı ve pek çok büyük moleküllü parametrenin ölçülmesinde kullanıımaktadır. Birçok çalışmada farklı antikorların neden olduğu interferans gösterilmiş fakat aynı durumun antivenomlar tarafından da olabileceği gösterilmemiştir. Bu çalışmanın amacı akrep antivenomunun immunassay yöntemde interferans oluşturma potansiyelinin deneysel olarak araştırılmasıdır. Bu çalışmada akrep antivenomunun 23 adet immunassay test üzerindeki interferans etkileri incelendi. Çalışma sonucunda serbest T3 seviyesi yüksek titre antivenomda $\% 13.09$ 'luk bir sapma gösterdi. Fertilite testlerinden progesteron seviyesi düşük titrede $\% 10.58$ oranında, testosteron seviyesi \%14.57 oranında negatif interferansa uğramıştır. Parathormon seviyelerinde düşük ve yüksek titre antivenom maruziyetinde \%11-16 arasında negatif interferans gözlenmiştir. Kütle kreatin kinaz MB testi \%7.35-21.58 oranında negatif interferansa, troponin I testi \%3-8.9 oranında pozitif interferansa uğramıştır. Özellikle kardiyak testlerin yanlış negatif bulunması kardiyak komplikasyonların atlanmasına neden olacağından hayati öneme sahiptir. Tümör markırları içinde en çok negatif interferansa maruz kalan test \%28.65-28.9 oranı ile kanser antijeni 19-9 oldu. Çoğu klinisyen tarafından bilinmeyen interfernas etki immunassay testlerde hatalı ölçüme neden olabilecek birer risk faktörüdür. Tedavi sırasında oluşabilecek bu tür durumlarla karşılaşmamak için hastane bilgi yönetim sistemleri ile klinisyenler önceden uyarılabilir. Interferansın neden olduğu hatalı test sonuçları malpraktislerle karşılaşma riskini arttırmaktadır. Sonuç olarak klinisyenler immunassay tekniklerden daha iyi yöntemler bulunana kadar laboratuvar testlerini değerlendirirken interferansa karşı dikkatli olmalıdır.
\end{abstract}

Anahtar Kelimeler: Skorpionizm, Antivenom, interferans, Immunassay.

\section{Experimental Investigation of Interference Effect of Scorpion Antivenom on Immunoassay Method}

Abstract: The original treatment of scorpionism is intravenous antivenom infusion. It is known that antivenom causes clinically allergic reactions, however potential interference effect of scorpion antivenom is unknown. The aim of present study was to investigate the potential of antivenom interference in immunosassay methods. In this study, $50 \mathrm{uL}$ and $100 \mathrm{uL}$ scorpion antivenom was added to 23 immunassay tests used for measuring T3, progesterone, testosterone, parathormone, creatin kinase, cancer antigen and troponin-I concentrations. The free T3 level showed a deviation of $13.09 \%$ in high titer antivenom.Progesterone levels were low in the fertility test at $10.58 \%$ and testosterone level was $14.57 \%$ at the low level. Rate of free T3 deviation was $13.09 \%$ in high titer of antivenom. In fertility tests, it was observed that levels of progesterone and testosterone decreased between $10.58-14.57 \%$ in low titre antivenom exposure. Negative interference was observed between $11-16 \%$ in low and high titre antivenom at parathomone levels.Mass creatine kinase MB test exposured 7.3521.58\% negative interference and troponin-I test introduced positive interference. Especially, the false negative results of cardiac test have a vital proposition because it will cause cardiac complications to be skipped. The most negative interference was observed for Cancer Antigen 19-9 concentration with a rate of $28.65-28.9 \%$. For all immunoassay measurements, every antibody is a risk factor that cause false negative or positive test result. Therefore, clinicians should be careful to confirm diagnostic laboratory tests until better methods than immunoassay techniques are found.

Keywords: Scorpionism, Antivenom, Interference, Immunoassay.

\section{Giriş}

Skorpionizm dünyanın bazı bölgelerinde yaygındır ve gerçek bir halk sağlığı problemidir. Multiorgan disfonkiyonuna neden olarak ölümle sonuçlanabilmektedir (Khattabi ve ark., 2011). Bu tür vakalarda tek tedavi seçeneği antivenom kullanımıdır (Theakston ve ark., 2003). Elde edilen antivenomun antidotal fraksiyonu, tam IgG, Fab veya $F$ (ab) 2'dir. (Gutiérrez ve ark., 2003).
Skorpionizm maruziyetinde intravenöz antivenom uygulanması ile sistemik belirtiler 6-24 saat içinde kaybolmasına rağmen, multiorgan disfonksiyonu açısından takip gereklidir (Valikhanfard-Zanjani ve ark., 2016). Venom organlara zarar verdiği gibi antivenomlar da alerjik ve anaflaktik reaksiyonlara neden olabilmektedir. Antivenom tedavi sonrası organ fonksiyonlarının monitörizasyonunda 
diagnostik ve prognostik olarak önemli olan laboratuvar parametrelerinin ne kadar interfere olduğu hakkında yeterince veri bulunmamaktadır. İmmunassay yöntemin kullanıldığı analizlerde interferans pek çok klinisyen tarafından farkında olunmayan hatta bilinmeyen ciddi bir sorundur (Ismail ve ark., 2002). İnterferans, “örnekte bulunan bir maddenin, analit için genellikle konsantrasyon veya aktivite olarak ifade edilen, sonucun doğru değerini değiştiren etkisi" olarak tanımlanmaktadır (Thompson ve ark., 2008). İmmunassay metotun kullanıldığı kitler, kompleks biyolojik reaktifleri (özellikle immunglobulinler) içerdiklerinden dolayı ölçüm sırasında başka kompleks moleküllerle interferansın farklı türlerine hassasiyet göstermektedirler. İmmunglobulinler, immunassay metotun reaktiflerinde enzim işaretli immunglobulinler ile yarışarak veya immunkompleks oluşturarak test sonuçlarında yanlış pozitiflik veya yanlış negatiflik oluşturabilir (García-González ve ark., 2016; Sturgeon ve ark., 2011). Interferans bu şekilde doğru test sonucunu gizleyerek gereksiz klinik araştırmalara ve hasta için uygunsuz tedaviye yol açabilir. İmmunoglobulin içerikli ilaçların parenteral uygulanmasından sonra analit ölçümü yapıldığında immunassay metotlar kullanılıyorsa interferansın mümkün olabileceği düşünülerek hastaya yaklaşılmalıdır. Bu çalışmanın odak noktası immunglobulin içerikli akrep antivenomunun kemilüminesans akrodinyum ester tekniğinin kullanıldığı immunassay yönteminde oluşturduğu interferansın deneysel olarak araştırılmasıdır.

\section{Materyal ve Metot}

Deneysel olarak dizayn edilen çalışmada $5 \mathrm{cc}$ seviye 3 hormon kontrol solüsyonu (BIORAD lot no: 40323, Irvine, CA) ve troponin I için kardiyak markır kontrol solüsyonu (BIORAD cardiac markers plus controls lot:23662, Irvine, CA) kullanıldı. Liyolifilize kontrol solüsyonu 5 cc grade 1 distile su ile sulandırıldı ve 1 saat oda sıcaklığında bekletilerek rotator ile homojenize edildi. Daha sonra dilüsyonel etkiyi ortadan kaldırmak için 1 cc kontrol solüsyonuna $50 \mathrm{uL}$ distile su eklendi ve ADVIA Centaur XP (Siemens, Washington, DC) hormon otoanalizöründe 23 adet test [TSH (Tiroid Stimüle Edici Hormon), FT3 (Serbest T3), FT4 (Serbest T4), Ferritin, Folat, B12 (Vitamin B12), FSH (Folikül Stimüle Edici Hormon), LH (Lüteinizan Hormon), PRG (Progesteron), E2 (Estradiol), HCG (Human Koryonik Gonadotropin), Testosteron, PSA (Prostat Spesifik Antijen), Free PSA (Free Prostat Spesifik Antijen), Kortizol, PTH (Parathormon), Kütle CK-MB
(Kütle Kreatin Kinaz MB), Troponin I, CA15-3 (Kanser Antijeni 15-3), CA 19-9 (Kanser Antijeni 19-9), AFP (Alfa Feto Protein), CA125 (Kanser Antijeni 125), CEA (Karsinoembriyonik Antijen)] kemilüminesans akrodinyum ester yöntemi kullanılarak hormon otoanalizöründe 3 kere çalışıldı. İnterferansı gözlemlemek için ilk sulandırılan kontrol solüsyonundan $1 \mathrm{cc}$ ayrı bir godeye alınarak üzerine $50 \mathrm{uL}$ akrep antivenomu (THSK, serial number: AK20B) eklendi. $37^{\circ} \mathrm{C}$ de 30 dakika inkübe edildikten sonra aynı parametrelerin tekrar çalışılması sağlandı. Aynı işlemler bu kez 100 uL distile su ve $100 \mathrm{uL}$ antivenom eklenerek tekrarlandı. Rastgele hataların önüne geçebilmek için yapılan tekrarlı çalışmadan sonra, ortalama (mean) ve standart sapma (SD) değerleri ayrı ayrı hesaplandı. $50 \mathrm{uL}$ ve $100 \mathrm{uL}$ distile su eklenerek elde edilen hormon test sonuçları, aynı miktar antivenom eklenerek elde edilen ortalama sonuçlar arasındaki fark hesaplanarak yüzde sapma miktarları tespit edildi. "Hedef değerden sapma miktarının yüzde ifadesi olarak tanımlanan" BIAS değerleri SPSS v20 programı ile hesaplanarak, Şekil 1 ve Tablo 1'de gösterildi. Herhangi bir canlıya girişimsel işlem içermeyen deneysel modelimiz etik kurul onayı gerektirmemektedir. BİAS formülündeki c1 ifadesi distile su eklenmiş kontrol solüsyonunun konsantrasyonunu, c2 ifadesi antivenom eklenmiş kontrol solüsyonunun konsantrasyonunu ifade etmektedir.

$$
\text { BİAS }(\%)=\frac{c 2-c 1}{c 1} x 100
$$

\section{Bulgular}

Çalışma sonucu TSH, Ferritin, HCG, Kortizol, PTH, Kütle CK-MB, CA 19-9 testleri düşük ve yüksek konsantrasyon antivenom maruziyetinde negatif interferans gösterdi. Bütün testler içinde en fazla negatif interferans tümör markırı olan CA 19-9 testinde \%28.6-28.95 oranlarında meydana geldi. Sırasıyla kütle CK-MB \%7.35-21.58, PTH \%11.7816.85 arasında diğer testlerden daha fazla negatif interferansa uğrayan testler oldu. HCG, Ferritin ve TSH testlerinin negatif interferansa uğrama yüzdeleri \%0.53-9.51 arasında değişen oranlarda gerçekleşti. Pozitif interferansa uğrayan testlerden FT3 en fazla sapma (\%1.69-13.09) gösteren test oldu. Pozitif interferansa uğrayan diğer testlerin (FSH, CEA, CA 125, Troponin I) sapma miktarı \%0.038.9 arasındaydı. FT4, Folat, Vitamin B12, LH, PRG, E2, Testosteron, PSA, Free PSA, CA15-3, AFP testleri düşük konsantrasyon antivenom maruziyetinde 
\%0.4-14.57 oranında negatif interferans, yüksek konsantrasyon antivenom maruziyetinde \%0.81-
6.78 oranında daha düşük düzey pozitif interferans gösterdi (Tablo 1).

Tablo 1. Kontrol solüsyonuna eklenen antivenom miktarlarına göre testlerin interferansa maruziyet miktarlarının \% BIAS olarak ifadesi. (NI: Negatif İnterferans, PI: Pozitif Interferans, DTNI: Düşük Titrede Negatif İnterfrenas, YTPI: Yüksek Titrede Pozitif İnterferans).

\begin{tabular}{|c|c|c|c|c|c|c|c|c|}
\hline No & TEST & $\begin{array}{c}\text { Kontrol } \\
\text { solüsyonu } \\
+50 u L \text { distile } \\
\text { su } \\
\text { (mean } \pm \text { SD) } \\
\end{array}$ & $\begin{array}{l}\text { Kontrol } \\
\text { solüsyonu } \\
+50 \mathrm{uL} \\
\text { antivenom } \\
\text { (mean } \pm \text { SD) }\end{array}$ & $\begin{array}{c}\text { BIAS1 } \\
(\%)\end{array}$ & $\begin{array}{c}\text { Kontrol } \\
\text { solüsyonu + } \\
100 u L \\
\text { distile su } \\
\text { (mean } \pm \text { SD) } \\
\end{array}$ & $\begin{array}{c}\text { Kontrol } \\
\text { solüsyonu + } \\
100 \mathrm{uL} \\
\text { antivenom } \\
\text { (mean士SD) } \\
\end{array}$ & $\begin{array}{l}\text { BíAS2 } \\
\text { (\%) }\end{array}$ & Açıklama \\
\hline 1 & $\begin{array}{l}\text { Tiroid Stimule Edici Hormon } \\
(\mathrm{TSH})\end{array}$ & $41.37 \pm 0.78$ & $40.27 \pm 0.80$ & -2.65 & $36.82 \pm 0.88$ & $36.38 \pm 1.13$ & -1.18 & $\mathrm{NI}$ \\
\hline 2 & Serbest T3 (FT3) & $9.85 \pm 0.58$ & $10.02 \pm 0.63$ & +1.69 & $8.84 \pm 0.62$ & $10 \pm 0.73$ & +13.09 & $\mathrm{PI}$ \\
\hline 3 & Serbest T4 (FT4) & $2.91 \pm 0.06$ & $2.74 \pm 0.06$ & -5.95 & $2.57 \pm 0.09$ & $2.74 \pm 0.16$ & +6.78 & DTNI,YTPI \\
\hline 4 & Ferritin (FER) & $268.9 \pm 4.03$ & $243.33 \pm 4.04$ & -9.51 & $240.32 \pm 6.6$ & $239.03 \pm 11.28$ & -0.53 & $\mathrm{Ni}$ \\
\hline 5 & Folat (FOL) & $10.87 \pm 0.67$ & $10.82 \pm 0.37$ & -0.40 & $9.72 \pm 0.617$ & $10.28 \pm 0.64$ & +5.68 & DTNI,YTPI \\
\hline 6 & Vitamin B12 & $715.7 \pm 4.35$ & $689.8 \pm 1.99$ & -3.62 & $639.48 \pm 11.85$ & $672.37 \pm 18.86$ & +5.14 & DTNI,YTPI \\
\hline 7 & Folikül Stimule Edici Hormon & $57.05 \pm 0.83$ & $58.52 \pm 0.91$ & +2.59 & $50.7 \pm 1.3$ & $51.54 \pm 1.4$ & +1.64 & $\mathrm{PI}$ \\
\hline 8 & Lüteinizan hormon(LH) & $54.69 \pm 1.25$ & $50.53 \pm 1.95$ & -7.59 & $49.06 \pm 1.18$ & $50.85 \pm 1.42$ & +3.64 & DTNI,YTPI \\
\hline 9 & Progesteron (PRG) & $17.9 \pm 0.66$ & $16 \pm 0.4$ & -10.58 & $15.87 \pm 0.79$ & $16.11 \pm 0.44$ & +1.54 & DTNI,YTPI \\
\hline 10 & Estrodiol (E2) & $711.68 \pm 2.23$ & $676.77 \pm 4.72$ & -4.91 & $635.82 \pm 8.39$ & $641.01 \pm 21.77$ & +0.81 & DTNI,YTPI \\
\hline 11 & $\begin{array}{l}\text { Human Koryonik } \\
\text { Gonadotropin }\end{array}$ & $171.83 \pm 1.53$ & $161.1 \pm 3.42$ & -6.25 & $153.59 \pm 3.38$ & $152.47 \pm 7.59$ & -0.72 & $\mathrm{NI}$ \\
\hline 12 & Testosteron & $705 \pm 4.92$ & $602.29 \pm 3.16$ & -14.57 & $629.78 \pm 8.63$ & $666.9 \pm 23.49$ & +5.89 & DTNI,YTPI \\
\hline 13 & Prostat Spesifik Antijen (PSA) & $14.03 \pm 0.7$ & $12.91 \pm 0.46$ & -7.96 & $12.9 \pm 0.96$ & $13.43 \pm 0.6$ & +4.03 & DTNI,YTPI \\
\hline 14 & $\begin{array}{l}\text { Serbest Prostat Spesifik } \\
\text { Antijen }\end{array}$ & $8.35 \pm 0.15$ & $7.99 \pm 0.27$ & -4.31 & $7.45 \pm 0.19$ & $7.62 \pm 0.19$ & +2.35 & DTNI,YTPI \\
\hline 15 & Kortizol (KORT) & $39.13 \pm 0.6$ & $35.66 \pm 1.34$ & -8.86 & $34.73 \pm 0.92$ & $34.45 \pm 1.34$ & -0.80 & $\mathrm{NI}$ \\
\hline 16 & Parathormon (PTH) & $408.77 \pm 1.53$ & $339.9 \pm 2.88$ & -16.85 & $365.06 \pm 5.64$ & $322.03 \pm 8.27$ & -11.78 & $\mathrm{NI}$ \\
\hline 17 & $\begin{array}{l}\text { Kütle Kreatin Kinaz MB (Kütle } \\
\text { CK-MB) }\end{array}$ & $0.46 \pm 0.04$ & $0.36 \pm 0.005$ & -21.58 & $0.41 \pm 0.031$ & $0.38 \pm 0.01$ & -7.35 & $\mathrm{NI}$ \\
\hline 18 & Troponin I (TRO-I) & $2.87 \pm 0.16$ & $2.90 \pm 0.19$ & +3.0 & $2.80 \pm 0.13$ & $3.05 \pm 0.18$ & +8.9 & $\mathrm{PI}$ \\
\hline 19 & $\begin{array}{l}\text { Kanser antijeni 19-9 (CA 19- } \\
\text { 9) }\end{array}$ & $11.74 \pm 0.29$ & $8.38 \pm 0.21$ & -28.60 & $10.45 \pm 0.36$ & $7.42 \pm 0.22$ & -28.95 & $\mathrm{NI}$ \\
\hline 20 & Kanser antijeni 125 (CA 125) & $6.57 \pm 0.25$ & $6.66 \pm 0.15$ & +1.52 & $5.82 \pm 0.23$ & $5.87 \pm 0.2$ & +0.78 & $\mathrm{PI}$ \\
\hline 21 & Kanser antijeni 15-3 (CA 15-3) & $9.83 \pm 0.37$ & $9.23 \pm 0.35$ & -6.07 & $8.77 \pm 0.42$ & $9 \pm 0.23$ & +2.62 & DTNI,YTPI \\
\hline 22 & Alfa Feto Protein (AFP) & $208.37 \pm 3.07$ & $200.43 \pm 1.75$ & -3.81 & $187.21 \pm 4.20$ & $189.06 \pm 6.5$ & +0.98 & DTNI,YTPI \\
\hline 23 & $\begin{array}{l}\text { Karsinoembriyonik Antijen } \\
\text { (CEA) }\end{array}$ & $33.84 \pm 1.23$ & $33.85 \pm 0.18$ & +0.03 & $30.41 \pm 1.38$ & $31.85 \pm 0.87$ & +4.70 & PI \\
\hline
\end{tabular}

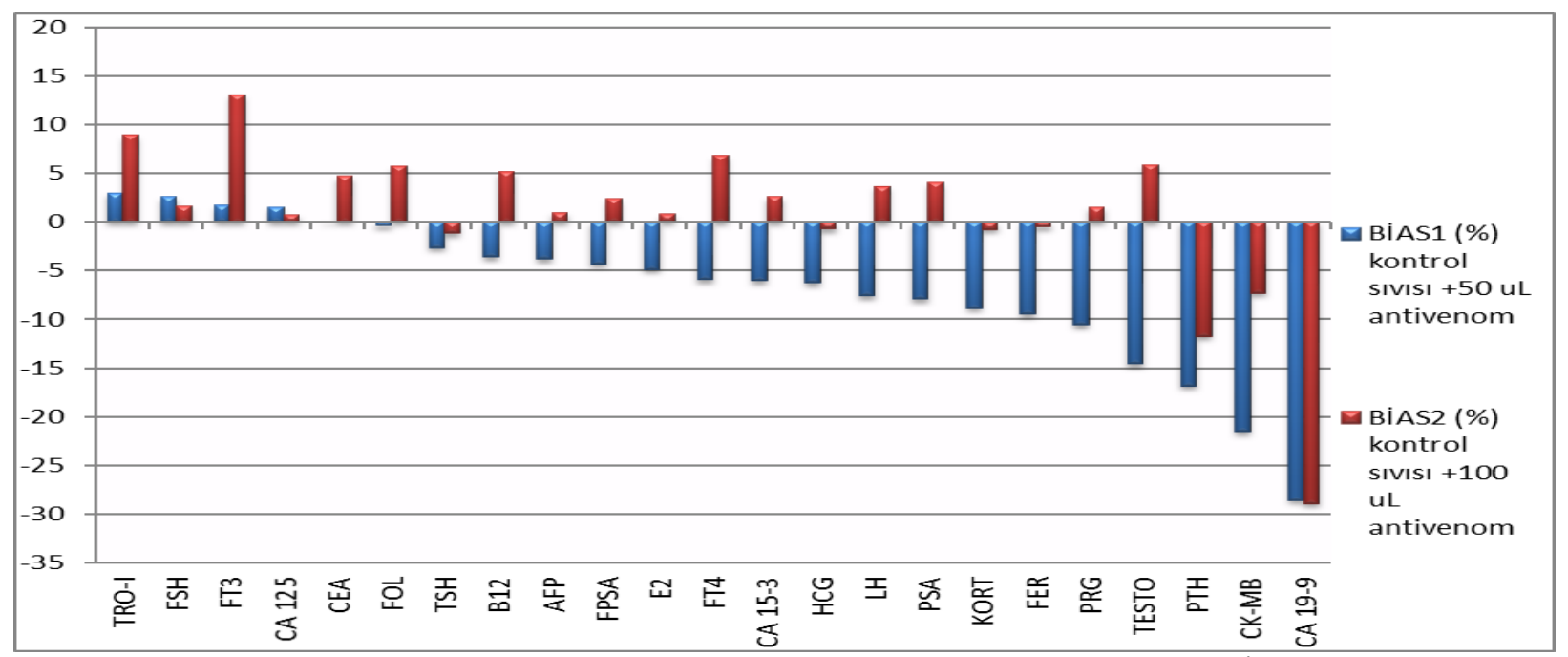

Şekil 1. 50uL ve $100 \mathrm{uL}$ eklenen antivenom miktarlarına göre testlerin hedef değerden sapma (BIAS) yüzdeleri. (TRO-I: Troponin-I, FSH: Folikül uyarıcı hormon, FT3: Serbest T3, CA 125: Kanser antijeni 125, CEA: Kanrinoembriyonik antijen, FOL: Folat, TSH: Tiroid uyarıcı hormon, B12: Vitamin B12, AFP: Alfa fetoprotein, FPSA: Serbest prostat spesifik antijen, E2: Estradiol, FT4: Serbest T4, CA 15-3: Kanser antijeni 15-3, HCG: Human koryonik gonadotropin, LH: Lüteinizan hormon, PSA: Prostat spesifik antijen, KORT: Kortizol, FER: Ferritin, PRG: Progesteron, TESTO: Testosteron, PTH: Parathormon, CK-MB: Kütle kreatin kinaz MB, CA 19-9: Kanser antijeni 19-9). 

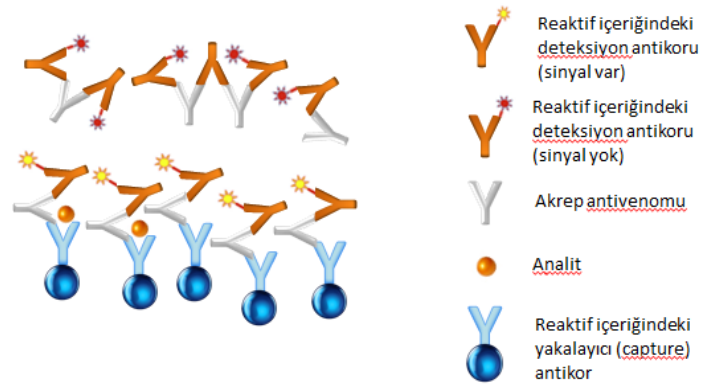

Şekil 2. İmmunassay metotta akrep antivenomu interferansına örnek. Antivenom hem yakalayıcı (capture) hem de deteksiyon antikorlarını bağlayabilir. Oluşan immunkompleks ile ortamda analit olmasa dahi deteksiyon antikorunda oluşan sinyal pozitif interferansa neden olur. Ortamdaki akrep antivenomu deteksiyon antikorunu fazla miktarda bağlarsa analit ortamda olsa dahi sinyal oluşmaz ve negatif interferansa neden olur.

\section{Tartışma ve Sonuç}

Akrep antivenomları skorpionizm vakalarında acilen kullanılması gereken immunglobulin içerikli antiserumlardır. Antivenomlar ekzojen kaynaklı immunglobulinlerin neden olduğu immun reaksiyonlara yol açabilirler (De Rezende ve ark., 1995). Vücuda enjekte edildikten sonra venom antijeninin yanında başka antijenlere de afinite gösterebilirler. İmmunassay yöntemle çalışılan testlerde kit içeriğindeki işaretli antikorlarla etkileşime girerek hatalı ölçümlere neden olma potansiyeline sahip olan antivenomlar, skorpionizm maruziyetinde organ disfonksiyon takibinde kullanılacak testlerin sonuçlarını interfere edebilirler. İmmunassay metotlar çoğunlukla büyük moleküllü hormonlar, vitaminler ve tümör markırlarının kan düzeyi ölçümünde kullanılırlar (Aydin, 2015; Taylor ve ark., 2015). Rutinde kullanılan birçok immunassay ölçüm tekniği bulunmaktadır (Wild, 2013). İmmunassay metotun kullanıldığı kompleks biyolojik reaktifler immunglobulin içerdiklerinden dolayı ölçüm sırasında başka kompleks moleküllerle interferansın farklı türlerine maruziyet göstermektedirler (Rauch ve ark., 2005). İmmunglobulinler immunassay metotun reaktiflerinde enzim işaretli immunglobulinler ile yarışarak veya immunkompleks oluşturarak serumda bulunan analitlerin hatalı düşük veya yüksek ölçülmesine neden olurlar (Şekil 2). Ortamda bulunan antivenom antikorlarının oluşturacağı immunkompleks yapının sinyal oluşturması durumunda pozitif interferans, sinyal oluşumunun engellenerek yanlış düşük sonuç oluşması durumunda negatif interferans meydana gelir. Interferans yanlış tanı ve tedaviye yol açabilir (García-González ve ark., 2016).

İnterferansların oluşturduğu hatalı ölçümlerle ilgili çeşitli vaka bildirimleri yapılmıştır. Kemilüminesans immunassay (CLIA) ve elektrokemilüminesans immunassay (ECLIA) metotu kullanılarak yapılan bir çalışmada tekrarlanan ölçümlerde klinik ile uyumsuz olarak yüksek TSH, ACTH, FSH, PTH, IGF-1, prolaktin, insan koryonik gonadotropin ve kalsitonin düzeylerinin kandaki heterofil antikorlardan kaynaklandığı tespit edilmiştir (Gulbahar ve ark., 2015). TSH ve gonadotropinler için yapılan bir çalışmada, 5310 hastanın 28 'inden alınan örneklerde immunglobulin kaynaklı interferans bulunmuştur (Ismail ve ark., 2002). 10 ülkede 66 laboratuvarda gerçekleştirilen geniş tabanlı başka bir araştırmada, hastalardan alınan numunelerin sonuçları incelenmiş ve 3445 sonuçtan \%8.7'sinin yanlış olduğu tespit edilmiştir. Yanlış ölçüm nedeni IgG içerikli otoimmun antikorların meydana getirdiği interferans olarak gösterilmiştir (Marks, 2002). IgG antikorları gibi IgA, IgM veya nadiren IgE de interferans oluşturabilir (Chatenoud ve ark., 1986; Frödin ve ark., 1992; McCarthy ve ark., 1988). Septisemisi olan hastalarda yapılan bir çalışmada kandaki IgM antikorlarının oluşturduğu interferans ile immunassay metotla çalışılan kardiyak troponin I, tirotropin, hCG, alfafetoprotein ve CA-125 testlerinde artmış yalancı pozitiflik ile karşılaşılmıştır (Covinsky ve ark., 2000).

Birçok antikor üzerinde yapılan interferans çalışmalarına rağmen daha çok IgG içerikli olan akrep antivenomlarının immunassay ölçüm tekniğinin kullanıldığı testlere olan etkisi araştırımamıştır. Çalışmamızda kemilüminesans akridinyum ester yöntemi ile ölçümü yapılan 23 farklı testin (TSH, FT3, FT4, Ferritin, Folat, B12, FSH, LH, PRG, E2, HCG, Testosteron, PSA, Free PSA, Kortizol, PTH, kütle CK-MB, Troponin I, CA 19-9, CA 125, CA 15-3, AFP, CEA) antivenom titresinden sapma miktarları gözlemlenmiştir. Rutinde sıkça kullanılan TSH düzeyleri akrep antivenomundan minimal düzeyde (\%1.8-2.65) etkilenmiştir. TSH testinin bu yöntem ile ölçüm hassasiyetinin arttırıldığı başka bir çalışmada da gösterilmiştir (Natrajan ve ark., 2010). Tiroid fonksiyon testlerinden FT4'deki sapma da minimal düzeyde olmuştur. Fakat FT3 seviyesi yüksek titre antivenomda \%13.09'luk bir sapma göstermiştir. Testler arasında farklılık gösterebilse de klinisyenler genellikle laboratuvar testlerinin $\pm \% 10$ hata payı olabileceğini öngörerek tanı ve tedaviye yaklaşırlar (Ayyıldız, 2016; Çelebiler ve ark., 2011). FT3 bu oranın üzerinde olsa da TSH ve FT4'deki sapma düzeyleri düşük seviyede kalmıştır. Tiroid fonksiyon 
bozukluğunda klinisyenler için primer önemli olan testler TSH ve FT4'dür. FT3'deki sapma oluştuğunda, FT4 ve TSH konsantrasyonları ile korele olmadığında klinisyenler tarafından hatalı ölçüm olarak tahmin edilebilmektedir. Fertilite testlerinden progesteron seviyesi düşük titrede \%10.58 oranında, testosteron seviyesi \%14.57 oranında negatif interferansa uğramıştır. Bu tür bir ölçüm hatasında fertilizasyon tarama testleri yapılan hastada yanlış progesteron seviyesi klinisyeni progesteron yetmezliğine bağlı infertiliteye, erkeklerde yanlış düşük testosteron seviyesi, hormonal yetmezliğe bağı infertiliteye yönlendirecektir. Hormon testlerinden in vitro şartlarda anstabil olarak bilinen parathormon (PTH) seviyeleri düşük ve yüksek titre antivenom maruziyetinde \%11-16 arasında negatif interferans göstermiştir. Bu düzeydeki bir sapma sınır değer PTH yüksekliği yaşayan hiperparatirodizmde hastalığın atlanmasına ve komplikasyonların kronikleşmesine neden olabilir. CLIA immunassay tekniğinin kullanıldığı başka bir çalışmada, IgG sınıfından olan romatoid faktörden (RF) kaynaklı pozitif interferans, PTH düzeylerinin yanlış yüksek ölçülmesine neden olmuştur. RF'nin serumdan uzaklaştırılması ile PTH sonuçlarının düzeldiği gözlemlenmiştir (Cavalier ve ark., 2008). Çalışmamızda kütle CK-MB testinde \%7.35-21.58 oranında negatif interferans gerçekleşmiştir. Özellikle skorpionizm maruziyetinde kardiyak testlerin yanlış negatif bulunması kardiyak komplikasyonların atlanmasına neden olacağından hayati öneme sahiptir. Kütle CK-MB'nin troponin I ile birlikte değerlendirilmesi faydalı olacaktır. Göğüs ağrısı olan hastalarda belli saat aralıklarında tekrar kütle CK-MB ölçümü yapılarak, testin yükselme eğilimine göre hastanın durum değerlendirilmesi yapılır. Akrep antivenomu kandan elimine edilinceye kadar interferans devam edeceğinden hasta kötüleşse bile tekrarlı ölçümlerde yanlış düşük sonuçlar elde edilme intimali yüksektir. Troponin I parametresi \%3-8.9 oranında pozitif interferansa uğramıştır. Kütle CK-MB'nin negatif interferansa, troponin I düzeyinin pozitif interferansa uğraması kardiyak komplikasyonun atlanmaması açısından avantaj gibi görünse de, yeterince yükselmemiş troponin I düzeyi olduğunda akut kardiyak komplikasyoların atlanma ihtimali söz konusu olacaktır. Anti-troponin antikorları ve hemolizli numunelerin interferanslarına bağlı olarak yanlış negatif troponin sonuçları bildirilmiş vakalar bulunmaktadır (Bais, 2010; Eriksson ve ark., 2005). Hemolizin troponin I seviyelerini negatif interfere ettiği bilinmektedir. Hemolizin de eklendiği bir interferans durumunda kardiyak komplikasyonu gösterecek herhangi bir laboratuvar kanıtı olmayacaktır. Kardiyak patolojiyi gösteren testlerin yanlış ölçümü her zaman mortalite riskini arttırma potansiyeline sahiptir. Çalışmamızda tümör markırları için de en çok negatif interferansa maruz kalan test \%28.65-28.9 oranı ile CA 19-9 oldu. 2006 yılında CA 19-9'un immunassay metot ile ölçümünde kandaki romatoid faktörden etkilendiği gösterilmiştir (Berth ve ark., 2006). Heterofil antikorların total PSA testinde pozitif interferansa neden olduğu bildirilmiştir (Morgan ve ark., 2001). Çalışmamızda ise total PSA testinde antikor yoğunluğuna göre düşük konsantrasyon antivenom varlığında \%7.96 oranında negatif interferans, yüksek konsantrasyon antivenom varlığında \%4.03 oranında pozitif interferans meydana geldi. Antikor yoğunluğuna göre bazen hem pozitif hem de negatif interferansın oluşması, immunkompleks veya yoğun antikor varlığının oluşturduğu çengel etkisine (hook effect) bağı olabilir. Bu tür tedavi amaçlı kullanılan antikorların kandan eliminasyon süreleri interferansın görülme süresini doğrudan etkileyecektir. Acil müdahale edilmesi gereken skorpionizm vakalarında elbette tümör markırı testi yüksekliği önemsiz olabilir. Fakat homeostazisi gösteren takip parametrelerinin negatif interferansla hatalı ölçülmesi hayati risk oluşturacaktır.

IgG bağlayan antikor olan heterofil anticisimciklerin (HAMA) ve RF gibi doğal antikorların hatalı sonuçlara yol açtığı birçok çalışmada gösterilmesine rağmen, aşı, intravenöz immunglobulin gibi terapotik olarak kullanılan antikor içerikli preparatların, hangi testi ne kadar interfere ettiği yeterince araştırılmamıştır (Krahn ve ark., 1999; Marks, 2002). Asemptomatik gidebilen birçok otoimmun hastalıkta kanda yükselen antikor seviyelerinin immunassay testleri interfere ederek, başka hastalıkları ne kadar gizlediğine dair yeterince bilgiye sahip değiliz. Doğru test sonuçlarını gizleyen interferans faktörleri malpraktislerle karşılaşma riskini arttırmaktadır. Deneysel olarak kullandığımız akrep antivenomu interferans oluşturan antikorlardan sadece bir tanesidir. Eksojen veya endojen kaynaklı tüm antikorlar immunassay testlerde bu potansiyele sahip birer risk faktörüdür. Bununla birlikte, birçok klinisyenin farkında olmadığı ve gerçekleşme zamanı öngörülemeyen interferansın tespit edilmesi, tekrarlı ölçümlerle de mümkün değildir. Preklinik uzmanlar bu tür etkileri bilseler dahi, hastalara uygulanan tedavi verilerine sahip olmadıklarından interferansı önceden tahmin etmeleri zordur.

Sonuç olarak hastaya ait interferansa neden olacak risk faktörleri (ilaç ve hastalık gibi) preklinik uzmanların onay ekranlarında gösterilerek 
interferansa maruz kalmış şüpheli sonuçlar uyarı notu tarzında sonuç bilgi ekranında gösterilebilir. İnvitro diagnostik test üreticisi şirketler tarafından ekzojen ve endojen antikorlardan etkilenmeyen teknikler geliştirilene kadar, klinisyenlerin bu tür hatalı sonuçlara karşı farkındalığının arttırılması, yanlış tanı ve tedavinin önlenmesi açısından hayati öneme sahiptir.

\section{Kaynaklar}

Aydin S, 2015: A short history, principles, and types of ELISA, and our laboratory experience with peptide/protein analyses using ELISA. Peptides, 72, 4-15.

Bais R, 2010: The effect of sample hemolysis on cardiac troponin I and T assays. Clin Chem, 56, 1357-59.

Berth M, Bosmans E, Everaert J, Dierick J, Schiettecatte J, Anckaert E, Delanghe J, 2006: Rheumatoid factor interference in the determination of carbohydrate antigen 19-9 (CA 19-9). Clin Chem and Lab Med (CCLM), 44, 1137-39.

Cavalier E, Carlisi A, Chapelle JP, Delanaye P, 2008: False positive PTH results: an easy strategy to test and detect analytical interferences in routine practice. Clinica Chimica Acta, 387, 150-52.

Chatenoud L, Baudrihaye MF, Chkoff N, Kreis H, Goldstein G, Bach JF, 1986: Restriction of the human in vivo immune response against the mouse monoclonal antibody OKT3. The Journal of Immunology, 137, 830-38.

Covinsky M, Laterza O, Pfeifer JD, Farkas-Szallasi T, Scott MG, 2000: An $\operatorname{IgM} \lambda$ antibody to Escherichia coli produces false-positive results in multiple immunometric assays. Clin Chem, 46, 1157-61.

De Rezende, Alves N, Dias MB, Campolina D, Chavez-Olortegui C, Diniz CR, Santos Amaral CF, 1995: Efficacy of antivenom therapy for neutralizing circulating venom antigens in patients stung by Tityus serrulatus scorpions. Am J Trop Med Hyg, 52, 277-80.

Eriksson S, Halenius H, Pulkki K, Hellman J, Pettersson K, 2005: Negative interference in cardiac troponin I immunoassays by circulating troponin autoantibodies. Clin Chem, 51, 83947.

Frödin JE, Lefvert AK, Mellstedt H, 1992: The clinical significance of HAMA in patients treated with mouse monoclonal antibodies. Cell biophysics, 21, 153-65.
García-González E, Aramendía M, Álvarez-Ballano D, Trincado P, Rello L, 2016: Serum sample containing endogenous antibodies interfering with multiple hormone immunoassays. Laboratory strategies to detect interference. Pract Lab Med, 4, 1-10.

Gulbahar O, Degertekin CK, Akturk M, Yalcin MM, Kalan I, Atikeler GF, Altinova AE, Yetkin I, Arslan M, Toruner F, 2015: A case with immunoassay interferences in the measurement of multiple hormones. The Journal of Clinical Endocrinology \& Metabolism, 100, 2147-53.

Gutiérrez JM, León G, Lomonte B, 2003: Pharmacokinetic-pharmacodynamic

relationships of immunoglobulin therapy for envenomation. Clin Pharmacokinet, 42, 72141.

Ismail AAA, Walker PL, Barth JH, Lewandowski KC, Jones R, Burr WA, 2002: Wrong biochemistry results: two case reports and observational study in 5310 patients on potentially misleading thyroid-stimulating hormone and gonadotropin immunoassay results. Clin Chem, 48, 2023-29.

Ismail AAA, Walker PL, Cawood ML, Barth JH, 2002: Interference in immunoassay is an underestimated problem. Ann Clin Biochem, 39, 366-73.

Khattabi A, Soulaymani-Bencheikh R, Achour S, Salmi LR, 2011: Classification of clinical consequences of scorpion stings: consensus development. Trans R Soc Trop Med Hyg, 105, 364-69.

Krahn J, Parry DM, Leroux M, Dalton J, 1999: High percentage of false positive cardiac troponin I results in patients with rheumatoid factor. Clin Biochem, 32, 477-80.

Marks, Vincent, 2002: False-positive immunoassay results: a multicenter survey of erroneous immunoassay results from assays of 74 analytes in 10 donors from 66 laboratories in seven countries. Clin Chem, 48, 2008-16.

McCarthy RC, Ryan FJ, McKenzie CM, 1988: Interference in immunoenzymometric assays caused by IgM anti-mouse IgG antibodies. Arch Pathol Lab Med, 112, 901-07.

Natrajan A, Sharpe D, Costello J, Jiang Q, 2010: Enhanced immunoassay sensitivity using chemiluminescent acridinium esters with increased light output. Anal Biochem, 406, 20413.

Rauch P, Zellmer A, Dankbar N, Specht C, Sperling D, 2005: Assayoptimierung: Störeffekte bei 
Immunoassays erkennen und vermeiden. Laborwelt, 4, 33-39.

Sturgeon CM, Viljoen A, 2011: Analytical error and interference in immunoassay: minimizing risk. Ann Clin Biochem, 48, 418-32.

Taylor AE , Keevil B, Huhtaniemi IT, 2015: Mass spectrometry and immunoassay: how to measure steroid hormones today and tomorrow. Eur J Endocrinol, 173, D1-D12.

Theakston RDG, Warrell DA, Griffiths E, 2003: Report of a WHO workshop on the standardization and control of antivenoms. Toxicon, 41, 541-57.
Valikhanfard-Zanjani E, Mirakabadi AZ, Oryan S, Goodarzi HR, Rajabi M, 2016: Specific Antivenom Ability in Neutralizing Hepatic and Renal Changes 24 Hours after Latrodectus dahli Envenomation. Journal of Arthropod-Borne Diseases, 10(2), 238-245.

Thompson M, Ellison SLR, 2008: A review of interference effects and their correction in chemical analysis with special reference to uncertainty. Accred Qual Assur, 10, 82-97.

* Yazışma Adresi: Ataman GÖNEL

Harran Üniversitesi, Tıp Fakültesi, Tıbbi Biyokimya Anabilim Dalı, Şanlıurfa, Türkiye.

E-mail: atamangonel@gmail.com 